\title{
PERAN PENDIDIKAN TINGGI HUKUM DAN URGENSI MAHASISWA DALAM MEWUJUDKAN HUKUM YANG BERKEADILAN
}

\author{
Syahrul Romadan \\ Fakultas Hukum, Universitas Diponegoro \\ JI. Prof. Soedarto, S.H., Tembalang, Semarang \\ Syahrulromadhan99@gmail.com
}

\begin{abstract}
This writing aims to determine the capacity of law school institute and law students in creating law enforcers with integrity, profesionalism, and being able to realize legal justice. Law enforcement in Indonesia that does not synergize with each other will hinder the realization of justice. Therefore, the existence of law school institute and law students as the forerunner of law enforcement must be questioned. The result of this study is that law enforcement in Indonesia still shows ineffectiveness in its operation. So the authors suggest that law school institution should be oriented to efforts to provide stimulus to students so that they are able to have critical, analytical, innovative and progressive thinking so that the essence of law enforcement, namely justice, can be achieved.
\end{abstract}

Keywords: Law School Institute; College Student; Justice

\begin{abstract}
Abstrak
Penulisan ini bertujuan untuk mengetahui kapasitas pendidikan tinggi hukum dan mahasiswa hukum dalam menciptakan penegak hukum yang berintegritas, profesional, serta mampu mewujudkan keadilan hukum. Penegakan hukum di Indonesia yang tidak saling bersinergi satu sama lain akan menghambat terwujudnya keadilan. Oleh karenanya eksistensi pendidikan tinggi hukum dan mahasiswa hukum sebagai cikal bakal penegakan hukum harus dipertanyakan. Hasil dari penelitian ini adalah bahwa penegakan hukum di Indonesia masih menunjukkan adanya ketidakefektifan dalam keberjalanannya. Sehingga penulis menyarankan kepada pendidikan tinggi hukum yang harus berorientasi kepada upaya memberikan stimulus kepada mahasiswa supaya mampu memiliki daya pikir kritis, analitis, inovatif dan progresif sehingga esensi dari penegakan hukum yaitu keadilan dapat tercapai.
\end{abstract}

Kata Kunci: Pendidikan Tinggi Hukum; Mahasiswa; Keadilan

\section{A. Pendahuluan}

Berangkat dari Pasal 1 ayat (3) Undang-Undang Dasar Negara Republik Indonesia Tahun 1945, sangat bisa diketahui bahwa Negara Indonesia adalah negara hukum. Menurut Kaelan, pengakuan dan perlindungan hak-hak asasi, peradilan yang bebas serta bersih dari pengaruh 
luar serta adanya kepastian hukum merupakan ciri-ciri dari negara hukum. ${ }^{1}$ Sehingga tujuan hukum akan tercapai apabila hukum dijadikan sebagai pedoman dalam setiap persoalan warga negara dan pemerintahan. Konsekuensi logisnya ialah kapasitas seluruh penegak hukum harus mampu bekerja secara optimal untuk mencapai esensi dari penegakan hukum itu sendiri, yaitu keadilan.

Martabat Negara Indonesia sebagai negara hukum terletak kepada kemampuannya untuk menegakkan keadilan hukum dalam kehidupan bermasyarakat. Di sisi lain, keberhasilan suatu negara dalam upaya meningkatkan martabatnya di bidang hukum dinilai dari penegakan hukum (law enforcement) yang baik, adil dan bertanggungjawab. Sebaliknya, suatu negara akan terlihat sangat jelas belum mampu memberikan perlindungan hukum kepada warga negaranya ketika apparat penegak hukumnya tidak menjalankan hukum sebagaimana mestinya. Maka dari itu, sistem hukum harus berjalan layaknya rangkaian organ masyarakat yang harus saling melengkapi dan memiliki kesadaran yang tinggi dalam hukum yang berlaku, terkhususnya dalam hal ini diperlukan keprofesionalan para penegak hukum.

Membicarakan penegak hukum yang profesional, tentu tidak terlepas dengan eksistensi pendidikan tinggi hukum yang sangat berperan penting dalam melahirkan mahasiswamahasiswa yang nantinya akan memenuhi kapasitas penegak hukum seperti yang diharapkan. Pendidikan tinggi hukum yang memberikan ilmu hukum secara holistik dan integral menjadikannya salah satu faktor penentu keberhasilan dalam menciptakan penegak hukum profesional. Melihat kondisi tersebut, bukan suatu kesalahan apabila muncul berbagai pertanyaan terkait eksistensi dan peran pendidikan tinggi hukum apabila melihat kondisi hukum Indonesia saat ini yang masih begitu menyedihkan. ${ }^{2}$

Dewasa ini, keberhasilan pendidikan tinggi hukum dalam mencetak penegak hukum yang profesional, diukur dari tingkat pelanggaran hukum yang dilakukan oleh penegak hukum itu sendiri. Semakin tinggi pelanggaran hukum yang dilakukan oleh penegak hukum maka keberhasilan pendidikan tinggi hukum dalam mencetak penegak hukum yang professional pun dinilai semakin rendah. Ironisnya, dalam perkembangannya, justru banyak penegak hukum yang melakukan pelanggaran hukum dan/atau bermasalah dengan hukum, seperti kasus suap yang dilakukan oleh Hakim Konstitusi Akil Mochtar, advokat senior O.C Kaligis, Toton, Dewi Suryana Hakim, hingga terbaru ini kasus jaksa Pinangki Sirna Malasati dan masih banyak juga yang lain.

1 Sahat Maruli Tua Situmaeng, "Kebijakan Kriminal Dalam Penegakan Hukum Untuk Mewujudkan Keadilan Dalam Perspektif Hak Asasi Manusia”, Res Nullius Law Journal, Vol. 1 No. 1, Januari 2019, hlm 27.

2 Muhammad Ali Safaat, 2015, Standarisasi Pendidikan Tinggi Hukum, Malang, Setara Press, hlm 21. 
Komisi Pemberantasan Korupsi dalam Pasal 11 ayat (1) Undang-Undang Nomor 19 Tahun 2019 tentang KPK, disebutkan bahwa lembaga antikorupsi berwenang melakukan penyelidikan, penyidikan dan penuntutan terhadap tindak pidana korupsi yang melibatkan aparat penegak hukum, penyelenggara negara dan orang lain yang ada kaitannya dengan Tindak Pidana Korupsi yang dilakukan oleh aparat penegak hukum atau penyelenggara negara. $^{3}$ Seperti di lansir dalam statistik penindakan tindak pidana korupsi oleh Komisi Pemberantasan Korupsi (KPK), secara berkala rekapitulasi yang dilaporkan dan diperharui diantaranya sebagai berikut: ${ }^{4}$

Tabel 1.

Rekapitulasi Penindakan Tindak Pidana Korupsi oleh KPK dalam Kurun Waktu Tahun 2015 s.d. 2021

\begin{tabular}{lccccccc}
\hline Penindakan & $\mathbf{2 0 1 5}$ & $\mathbf{2 0 1 6}$ & $\mathbf{2 0 1 7}$ & $\mathbf{2 0 1 8}$ & $\mathbf{2 0 1 9}$ & $\mathbf{2 0 2 0}$ & $\mathbf{2 0 2 1}$ \\
\hline Penyelidikan & 87 & 96 & 123 & 164 & 142 & 111 & 41 \\
Penyidikan & 57 & 99 & 121 & 199 & 145 & 91 & 22 \\
Penuntutan & 62 & 76 & 103 & 151 & 153 & 75 & 34 \\
Inkracht & 38 & 71 & 84 & 104 & 142 & 92 & 16 \\
Eksekusi & 38 & 81 & 83 & 113 & 136 & 108 & 18 \\
Total & $\mathbf{2 8 2}$ & $\mathbf{4 2 3}$ & $\mathbf{5 1 4}$ & $\mathbf{7 3 6}$ & $\mathbf{7 1 8}$ & $\mathbf{4 7 7}$ & $\mathbf{1 3 1}$ \\
\hline
\end{tabular}

Berdasarkan tabel tersebut, kenyataannya justru diketahui bahwa penindakan kasus korupsi masih terus menyasar pelaku (tersangka) dari jabatan menengah bawah (middle lower) sedangkan pelaku dengan jabatan menengah atas (middle upper) seperti mantan menteri, anggota DPR/Parpol, pengusaha nasional hingga aparat penegak hukum seperti yang telah disebutkan di atas seringkali tidak diusut dengan tuntas. ${ }^{5}$

Berdasarkan fakta tersebut, suatu hal yang wajar bahwa muncul pertanyaan: apa peran pendidikan tinggi hukum dalam mewujudkan hukum yang berkeadilan?. Berdasarkan uraian latar belakang di atas, maka dalam penulisan ini terdapat beberapa permasalahan yang dibahas, antara lain: Bagaimana Keadaan Penegakan Hukum di Indonesia? Bagaimana Peran Pendidikan Tinggi Hukum dalam Menciptakan Penegak Hukum yang Profesional? Bagaimana Upaya Pendidikan Tinggi Hukum dan Mahasiswa dalam Mewujudkan Hukum yang Berkeadilan?

4 Komisi Pemberantasan Korupsi, tersedia di website https://www.kpk.go.id/id/statistik/penindakan/109statistik, diakses pada tanggal 26 Juli 2021.

5 Indonesia Corruption Watch Jakarta, tersedia di website https://www.antikorupsi.org/sites/default/files/tren korupsi 2015 dan 2010-2015 - 151124 0.pdf, diakses pada tanggal 26 Juli 2021. 


\section{B. Pembahasan}

\section{Keadaan Penegakan Hukum Indonesia}

Pasal 1 ayat (3) Undang-Undang Dasar Republik Indonesia Tahun 1945 menyebutkan bahwa negara Indonesia adalah negara hukum. Konsep negara hukum harus diidealkan dengan menjadikan hukum sebagai panglima dari seluruh dinamika kenegaraan, politik bahkan ekonomi. ${ }^{6}$ Simbol dari hukum adalah penegakan hukum, sehingga penegakan hukum harus mampu membantu negara hukum untuk mewujudukan cita-cita hukum itu sendiri. Hukum yang sejatinya tercipta dan hadir untuk kebaikan, keberpihakan dan tentunya keadilan bagi kepentingan masyarakat luas justru dalam praktinya penegakan hukum yang ada lebih berpihak kepada kepentingan yang berkuasa dibandingkan kepentingan rakyat. Penegakan hukum yang lemah akan terlihat dengan jelas apabila hukum yang ada direduksi kepada persoalan prosedural semata tanpa melihat aspek lainnya.

Kewibawaan hukum terletak pada kemampuan penegak hukum dalam mengatasi setiap permasalahan hukum yang ada. Secara teoritis efektifitas penegakan hukum akan terpenuhi apabila 5 (lima) pilar hukum dapat berjalan dengan baik. Instrumen hukum, aparat penegak hukum, peralatan, masyarakat dan birokrasi adalah kelima pilar hukum yang dimaksud. ${ }^{7}$ Lemahnya penegakan hukum di Indonesia menjadikan aparat penegak hukum sebagai sorotan, dan disi lain kepercayaan masyarakat terhadap aparat hukum sudah sangat memprihatinkan, salah satu indikasinya adalah banyaknya tindakan rakyat kecil yang melakukan perbuatan main hakim sendiri (eigenrichting). ${ }^{8}$

Hukum di Indonesia serta penegakannya belum bisa dikatakan berjalan sesuai dengan arah dan tujuan hukum bersama. Permasalahan penegakan hukum (law enforcement) selalu memiliki tendensi terhadap ketidakseimbangan interaksi dinamis antara das sollen (harapan) dengan das sein (Kenyataan). ${ }^{9}$ Bukti dari penegakan hukum di Indonesia yang masih lemah dapat dilihat dari penyelesaian berbagai kasus yang tidak tertuntaskan, khususnya seperti praktik korupsi yang semakin meningkat, namun justru pelaku utamanya sangat sedikit yang terambah hukum dan/atau tidak divonis sebagai mana aturan hukum yang berlaku. Realitas penegakan hukum yang seperti itulah yang melukai hati rakyat kecil dan akan memunculkan sikap apriori masyarakat hingga ketidakpercayaan masyarakat kepada penegak hukum itu

6 Jimly Asshiddiqie, 2007, Pokok-Pokok Hukum Tata negara Indonesia Pasca Reformasi, Jakarta, Bhuana IImu popular, hlm 297.

7 Bambang Sutiyoso, 2005, Aspek-Aspek Perkembangan Kekuasaan Kehakiman di Indonesia, Yogyakarta, UII Press, hlm 78.

8 Rosdalina Bukido, "Paradigm and Reality of Law Enforcement in Indonesia", Jurnal Ilmiah Al-Syir'ah, Vol. 4, No 1, 2006, hlm 2

9 Rif'ah Roihanah, "Penegakan Hukum di Indonesia: Sebuah Harapan dan Kenyataan", Justicia Islamica, Vol. 12, No 1, 2015, hlm 40-41. 
sendiri. Berangkat dari kondisi tersebut, sudah suatu keharusan bagi kita untuk bercermin kembali pada tujuan akhir hukum itu sendiri yaitu untuk menciptakan keadilan.

Penegakan hukum di Indonesia yang masih sering terjadi penyimpangan dalam hukum, Sidharta menyampaikan hal tersebut dengan apa yang dinamakan sebagai jurang hukum, dimana jurang hukum tersebut menjadi sangat terbuka ketika perkiraan terhadap peristiwaperistiwa konkret yang akan terjadi di kemudian hari tidak mampu dirumuskan secara tepat dan lengkap oleh pembentuk undang-undang. ${ }^{10}$ Konsekuensinya adalah jika hal tersebut tidak dengan tepat memenuhi kebutuhan terhadap peristiwa konkret, maka pemaknaan terhadap ketentuan normatif dapat diperluas atau dipersempit olehnya. ${ }^{11}$ Kalangan akademisi hukum menyebutnya sebagai penemuan hukum yang justru mengisi celah jurang hukumnya itu sendiri. $^{12}$

Menurut Moch Koesnoe, di dalam Pembukaan dan Undang-Undang Dasar Negara Republik Indonesia Tahun 1945, terkandung berbagai nilai dasar tata hukum yang merupakan rechtsidee hukum, nilai dasar tersebut secara ringkas meliputi: ${ }^{13}$ (1) hukum itu berwatak melindungi; (2) hukum itu mewujudkan keadilan; (3) hukum itu bersifat kerakyatan; (4) hukum adalah pernyataan kesusilaan dan moralitas yang tinggi baik dalam bentuk peraturan atau dalam pelaksanaannya sebagaimana yang diajarkan dalam ajaran agama dan rakyat Indonesia. Nilai-nilai tersebutlah yang harus tercermin dalam realita penegakan hukum di Indonesia, dimana terciptanya keadilan di masyarakat menjadi esensi utama dari tujuan hukum Negara Indonesia.

\section{Peran Pendidikan Tinggi Hukum dalam Menciptakan Penegak Hukum yang Profesional}

Persoalan profesionalitas penegak hukum sangat berkaitan erat dengan tata-kelola Sumber Daya Manusia (SDM), terkhususnya dalam pengelolaan SDM di pendidikan tinggi hukum yaitu mahasiswa dan/atau Sarjana Hukum. Tujuan pendidikan tinggi hukum sangat perlu untuk ditetapkan mengingat pendidikan hukum di Indonesia terus berkembang, meskipun di sisi lain hingga saat ini belum ada kesepakatan terkait rumusan dan tujuan pendidikan hukum dari

10 Ucuk Agiyanto, "PENEGAKAN HUKUM DI INDONESIA: Eksplorasi Konsep Keadilan Berdimensi Ketuhanan", Hukum Ransendental, Vol. , No. , Tahun, hlm 495.

11 Arief Sidharta, "Pendekatan Hukum progresif dalam Mencairkan Kebekuan Produk Legislasi," dalam Moh. Mahfud MD, Sudharta, Sunaryani Hartono, et.al., 2013, Demokrasi dan Gerakan Pemikiran Hukum Progresif (Konsorsium Hukum Progresif Universitas Diponegoro Semarang), Yogyakarta, Thafa Media.

12 Ucuk Agiyanto, Loc Cit.

13 Muhammda Khambali, "Fungsi Filsafat Hukum dalam Pembentukan Hukum di Indonesia", Supremasi Hukum, Vol. 3, No. 1, Juni 2014, hlm 11-12. 
setiap institusi pendidikan tinggi hukum, baik Fakultas Hukum, Fakultas Syariah hingga Sekolah Tinggi Hukum. ${ }^{14}$ Hal tersebut pun harus mengingat bahwa prinsip ideal dari pendidikan tinggi hukum adalah pendidikan tinggi hukum harus dapat mengimplementasikan aspek aksiologi dari pendidikan hukum secara tepat. ${ }^{15}$ Sehinggan kapasitas (capacity building) mahasiswa wajib dijadikan sebagai konsep dan prioritas kebijakan pendidikan tinggi hukum sebagai salah satu langkah menciptakan penegak hukum yang memiliki rasa profesionalitas tinggi.

Pendidikan tinggi hukum harus mampu menjadi pelopor dalam mewujudkan paham yang luhur serta mulia. Pendidikan tinggi hukum ketika mampu menjalankan prinsip integritas dalam setiap lini kehidupan pada dasarnya telah sukses menerapkan peran strategisnya dalam melahirkan mahasiswa-mahasiswa yang mempunyai paham dan prinsip berupa berbagai nilai moralitas yang sangat memengaruhi tingkat keprofesionalitasannya sebagai penegak hukum nantinya.

Di sisi lain, mahasiswa hukum sebagai agen perubahan (agent of change) diperlukan untuk menjadi garda terdepan penegakan hukum yang keadaannya semakin hari semakin menyedihkan. Mahasiswa dinilai sebagai entitas terpelajar, berintelektualitas serta mempunyai kepribadian mulia, memiliki peran yang sama strategisnya seperti pendidikan tinggi hukum untuk benar-benar memenuhi harapan masyarakat untuk membentuk suatu lembaga hukum atau penegak hukum yang mampu menjalankan sistem dan tata kelola hukum yang profesional.

Dikotomi antara pendidikan tinggi akademik dan pendidikan keahlian profesi menjadi persoalan lain diluar internalisasi nilai hukum di masyarakat. Di satu sisi, pendidikan akademik hukum diarahkan untuk membentuk mahasiswa agar memiliki pengetahuan dan keterampilan mumpuni secara akademik, namun di sisi lain pendidikan keahlian profesi justru memprioritaskan arah pendidikan untuk melaksanakan praktik sebagai profesi hukum, seperti pengacara, jaksa, hakim, notaris dan lain sebagainya.

Iklim pendidikan tinggi hukum seperti di atas sebenarnya tidak lagi sesuai dengan perkembangan keilmuan hukum yang sekarang. Sebagaimana disampaikan oleh Barda Nawawi Arief bahwasannya, keberadaan pendidikan tinggi hukum bukan hanya untuk melakukan proses pembelajaran untuk menghasilkan Sarjana Hukum yang memiliki kemampuan akademik saja, namun juga untuk melaksanakan tugas keilmuan yang dimiliki

14 Hikmahanto Juwana, 2003, Memikirkan Kembali Sistem Pendidikan Hukum di Indonesia, Jurnal Jentera, 2003, hlm 89-94.

15 Titon Slamet Kurnia, Sri Harini Dwiyatmi, Dyah Hapsari, 2013, Pendidikan Hukum, Ilmu Hukum dan Pendidikan Hukum di Indonesia Sebuah Orientasi, Yogyakarta, Pustaka Pelajar, hlm 44. 
serta tugas nasional dalam rangka pengembangan dan pembaharuan hukum nasional. ${ }^{16}$ Maksud dari penyampian tersebut ialah pendidikan tinggi hukum sebagai lembaga formal serta mahasiswa hukum sebagai calon penegak hukum nantinya, tidak hanya menguasai hukum positif saja, namun juga mempunyai kecerdasan untuk mengembangkan ilmu, pemikiran, pengetahuan dan pemahaman terhadap hukum yang senyata terjadi di masyarakat nantinya.

Perkembangan hukum harus mampu diikuti oleh pemahaman dan pemikiran terhadap hukum itu sendiri. Disadari atau tidak, bahwa profesi hukum sangatlah beragam sehingga tidak hanya terpusatkan dalam ranah penyelesaian konflik seperti Advokat, Jaksa, Polisi, Hakim, namun juga dalam ranah pencegahan konflik seperti legal drafter, legal officer, konsultan bidang hukum, notaris dan lain sebagainya. Seluruh lapangan pekerjaan bidang hukum tersebut tentu dipengaruhi oleh pendidikan tinggi hukum sebagai gerbang terdepan menciptakan mahasiswa hukum yang memiliki kapasitas mumpuni untuk menjadi penegak hukum profesional sesuai dengan bidang profesinya masing-masing.

Kondisi tersebut di atas, menjadikan latar belakang lahirnya Peraturan Presiden Nomor 8 Tahun 2012 tentang Kerangka Kualifikasi Nasional Indonesia (KKNI) yang berusaha menyeimbangkan akademik dengan kemampuan non akademik untuk menunjang kompetensi kerja mahasiswa hukum nantinya. Implementasi KKNI tersebut dalam kenyataannya bisa terlihat dengan diajarkannya mata kuliah Ilmu Perundang-Undangan dan Teknik Perancangan Peraturan Perundang-Undangan (Legal Drafting) serta penyelesaian sengketa di luar pengadilan, yang selama ini fokus pembelajaran hanya kepada keterampilan beracara di pengadilan.

Dengan adanya $\mathrm{KKNI}$ tersebut, mencerminkan bahwa pendidikan tinggi hukum mulai menyadari dalam praktiknya nanti keprofesionalan seorang penegak hukum tidak serta merta dilihat hanya dari ijazah yang dimilikinya, namun juga dari pemahaman teoristis bidang pengetahuan, kemampuan mengaplikasikan keahlian dalam penyelesaian masalah, pengambilan keputusan dan tanggungjawab dalam pekerjaan yang dipercayakan padanya. Sehingga sangat diperlukan kebijakan pendidikan tinggi hukum diimbangi dengan pemahaman mahasiswa hukum untuk perlunya menanamkan karakter berintegrasi, bermoral baik dan profesional.

16 Syaifuddin dan Ade Kosasih, "Reorientasi Arah Kebijakan Pendidikan Tinggi Hukum dalam Upaya Membentuk Penegak Hukum Profesional”, Vol. 3, No. 2, 2018, hlm 160. 


\section{Upaya Pendidikan Tinggi Hukum dan Mahasiswa dalam Mewujudkan Hukum yang Berkeadilan}

Keadilan selalu dijadikan bahan peredebatan dalam dunia hukum, karena pada prinsip keadilan merupakan tujuan dari lahirnya hukum itu sendiri. Banyaknya kasus yang tidak terselesaikan dan justru dibawa ke ranah perpolitikan menjadikan peradilan atau keadilan tidak ditemukan dalam keadaan yang sebenarnya karena kebenaran hukum serta keadilan telah di rekayasa dengan cara yang sangat sistematik. ${ }^{17}$ Disini sangatlah diperlukan peran penegak hukum yang seharusnya mampu menjadi panglima dalam menegakkan keadilan, bukan menjadikan hukum sebagai alat kekuasaan.

Di sisi lain, indikator untuk mewujudkan hukum yang berkeadilan haruslah ditopang dengan kinerja penegak hukum yang profesional dengan kedudukannya sebagai penopang harapan masyarakat untuk menciptakan keadilan, sehingga kinerja profesional dari para penegak hukum bukanlah suatu hal yang bisa ditawar dan diperjual belikan nilainya demi mewujudkan tatanan hukum yang berkeadilan dan bertanggungjawab sebagaimana harapan masyarakat dan negara pada khususnya.

Lahirnya penegak hukum yang mampu mewujudkan keadilan hukum, tidak pernah bisa terlepas dari perbaikan dan pembenahan sektor pendidikan tinggi hukum di Indonesia yang selama ini terdapat ketidaksinkronan antar berbagai kebijakan menjadi tuntutan yang menggejala dewasa ini. Pendidikan hukum selama ini cenderung mengejar profesi dan ini mempunyai side effect dimana buah karya profesi adalah sikap untuk memperlakukan pengetahuan hukum sebagai urutan prosedur dan mekanisme. ${ }^{18}$ Makna mekanisme tersebut ialah bahwa berbagai unsur dalam hukum dilaksanakan harus sesuai ketentuannya, pendek kata ilmu hukum menjadi lebih positivistik. Tradisi hukum tersebut memposisikan kepastian menjadi kunci utama dalam sistem berhukum dengan memfokuskan terhadap aturan tertulis daripada aturan tidak tertulis dan/atau hukum kebiasaan. Apabila hal tersebut terus menerus dijalankan maka, hal yang lumrah apabila dunia hukum dipenuhi kepentingan-kepentingan politis praktik oleh sebagian orang yang menjadi pihak dalam memformulasikan hukum.

Apabila dipahami secara mendalam, dapat diketahui bahwa terdapat perbedaan tujuan pendidikan hukum dari waktu ke waktu meskipun tidak ada perbedaan signifikan dari lulusan setiap pendidikan tinggi hukum. Lulusan hukum dari tahun ke tahun terkesan legalistik dan tidak

17 Inge Dwisvimiar, “Keadilan dalan Perspektif Filsafat Ilmu Hukum”, Jurnal Dinamika Hukum, Vol. 1, No. 3, September 2011, hlm 522.

18 Arief Budiono, Siti Syahida Nurani, Ucuk Agiyanto, "Pendidikan Hukum yang Bervisi Keadilan Berdasarkan Ketuhanan Yang Maha Esa", Prosiding Konferensi Nasional ke-6:Sosial dan Politik, Pemikiran Islam, Hukum, Kesehatan, Yogyakarta, Program Pascasarjana Universitas Muhammadiyah Yogyakarta, 8-9 September 2017, hlm 124. 
memiliki perbedaan signifikan dari lulusan di masa pemerintahan Kolonial, bahkan cenderung tidak memenuhi berbagai tujuan pendidikan hukum pasca Indonesia merdeka. ${ }^{19}$ Apabila dikembangkan lebih lanjut lagi, maka akan diketahui bahwa system hukum yang dianut oleh suatu negara menentukan arah kebijakan yang diterapkan oleh pendidikan tinggi hukum dalam proses pembelajarannya.

Tradisi hukum eropa continental (civil law system) sangat memengaruhi sistem hukum Indonesia dengan menjadikannya bercirikan formalistic, legalistic dan positivistic. Tradisi demikian lebih mengarahkan pendidikan hukum untuk menekankan pada pembelajaran yang bersifat doktrinal. Materi yang teoritik dan metode penyampaian pembelajaran yang konvensional dan bersifat monolog, menjadikan dosen sebagai narasumber utama sedangkan mahasiswa bersifat pasif dan hanya sebagai pendengar. Akibatnya adalah sikap kritis dan analitis mahasiswa terfokus kepada kepastian hukum yang dijelmakan melalui peraturan perundang-undangan sehingga tidak leluasa dalam memikirkan dan menyikapi berbagai nilai hukum yang harus dijadikan tombak perjuangan seperti halnya keadilan, kemanfaatan dan kasih sayang.

Berbeda halnya apabila fakta di atas kita sandingkan dengan negara penganut tradisi hukum common law. Hal yang ditekankan oleh negara penganut common law dalam proses pembelajaran pendidikan tinggi hukum adalah dalam hal praktis (practical use). Negara penganut common law menjadikan kebiasaan sebagai pedoman untuk mendasarkan hukumnya atau dengan kata lain, setiap pebuatan hukum telah ada di kehidupan masyarakat berupa kebiasaan, tinggal bagaimana penegak hukum menerapkan hukum itu sendiri. Terhadap segala perbuatan yang belum ada pengaturan tersendiri, maka kehadiran hakim dalam keleluasaannya menentukan dan/atau membentuk hukum dengan penuh tanggung jawab sangat diutamakan.

Hukum di negara penganut common law tidak hanya berorientasi kepada penciptaan dan/atau pembaharuan hukum saja, namun juga berorientasi kepada penerapan hukumnya. Nuansa tradisi yang diusung oleh negara penganut common law, menjadikan arah pembelajaran hukum lebih bersifat praktis, sehingga mahasiswa pendidikan tinggi dapat terstimulasi untuk memunculkan sikap kritis analitis dalam setiap pembelajaran kasus yang sedang diberikan. Mahasiswa tidak akan hanya terikat kepada nilai kepastian hukum, namun juga mengarahkan kepada nilai moral berupa tanggung jawab terhadap keadilan dan kebenaran.

Ketika membicarakan kondisi di lapangan, diketahui bahwa stereotip masyarakat terhadap setiap mahasiswa dan/atau lulusan pendidikan tinggi hukum adalah sangat legalistik, ahli menghafalkan dan patuh terhadap doktrin. Pola pembelajaran hingga stereotip masyarakat

19 Ibid, hlm 131. 
terhadap pendidikan hukum hanya akan membentuk penegak hukum yang terampil, memahami hingga menghafal peraturan yang ada, namun minim nurani. Ketika nilai-nilai hukum tidak dapat diberjalankan secara keseluruhan, maka tujuan hukum berupa keadilan akan terciderai. Hal ini sejalan dengan pendapat Satjipto Rahardjo, bahwa pemikiran hukum untuk manusia harus dikembalikan menjadi filosofi dasar berhukum. ${ }^{20}$ Berangkat dari filosofi ini, olehnya titik orientasi hukum ditentukan oleh manusia, sehingga hal tersebut yang menjadikan hukum progresif berideologi "hukum yang pro-keadilan serta hukum yang pro-rakyat".

Kedepannya, pendidikan tinggi hukum harus mampu memberikan pengajaran hukum yang tidak sebatas fokus pada keterampilan akademik, namun juga memiliki kemampuan "problem solving", karena pada dasarnya mahasiswa hukum akan dihadapkan pada keadaan mayarakat di kenyataannya nanti. Sehingga mahasiswa hukum sebagai penegak hukum nantinya dapat diandalkan oleh masyarakat untuk memiliki idealisme, moral, perilaku yang memprioritaskan keadilan, kejujuran, kebijaksanaan dan tanggungjawab.

Oleh karena hal tersebut di atas, esksistensi pendidikan tinggi hukum sebagai pengawal penegakan hukum harus mampu mewujudkan pendidikan bersistem komprehensif dengan prioritas pembaharuan hukum nasional, sehingga mampu menciptakan penegak hukum yang profesional dengan kemampuan penalaran kritis, idealis serta mampu memahami berbagai nilai yang ada dalam, sehingga nantinya dapat mewujudkan hukum yang berkeadilan.

\section{Simpulan}

Proses penegakan hukum Negara Indonesia sangat jauh dari tujuan hukum kita semua, sehingga tujuan hukum yaitu keadilan masih belum bisa tercapai. Tidak mengherankan apabila kemudian muncul kalimat hukum tumpul ke atas namun hukum tajam ke bawah, karena pada faktanya masih terdapat banyak kasus hukum yang belum terselesaikan dengan sebagaimana mestinya dan menjadi problematika dalam penegakan hukum Indonesia. Hukum dapat berjalan secara efektif apabila seluruh pihak terkhususnya penegak hukum mampu menjunjung tinggi nilai-nilai hukum yang berada dalam masyarakat dan tentunya mengutamakan intelektualitasme dan integritas dalam menghadapi berbagai permasalahan hukum di kehidupan masyarakat.

Terbentuknya mahasiswa hukum sebagai penegak hukum yang berintegritas, profesional dan tentu berkeadilan yang sesuai dengan harapan masyarakat ditentukan oleh eksistensi pendidikan tinggi hukum itu sendiri. Pendidikan tinggi hukum harus mampu menjadikan mahasiswa hukum sebagai penegak hukum yang nantinya tidak hanya menggunakan kacamata kuda, dalam artian mengabaikan keadilan dan hanya mengutamakan prosedur

20 Satjipto Rahardjo, 2007, Mendudukkan UUD, Suatu Pembahasan dari Optik IImu Hukum Umum, Semarang, Undip Press, hlm 11. 
belaka. Perubahan paradigma dan sistem pendidikan hukum secara menyeluruh, transparan dan holistik sangatlah diperlukan, sehingga mampu memperbaiki krisis hukum yang telah tercipta.

Solusi terbaik untuk menjawab permasalahan tersebut adalah, pendidikan tinggi hukum harus mampu meciptakan formula kebijakan pendidikan yang tidak hanya menguatkan aspek akademik mahasiswa, namun juga penguatan aspek dalam nilai jujur, adil dan bertanggungjawab hingga aspek etika (attitude) wajib dimiliki oleh setiap penegak hukum atau dengan kata lain harus mampu menjadikan dunia pendidikan tinggi hukum yang memiliki ketajaman kurikulum yang seimbang antara lingkungan akademis dan praktis, yang nantinya secara bersama-sama dapat mewujudkan hukum yang berkeadilan secara substansial di seluruh wilayah Indonesia.

\section{DAFTAR PUSTAKA}

\section{Buku:}

Asshiddiqie, Jimly, 2007, Pokok-Pokok Hukum Tata negara Indonesia Pasca Reformasi, Jakarta, Bhuana IImu popular.

Juwana, Hikmahanto, 2003, Memikirkan Kembali Sistem Pendidikan Hukum di Indonesia, Jurnal Jentera, 2003.

Kurnia, Titon Slamet, Sri Harini Dwiyatmi, Dyah Hapsari, 2013, Pendidikan Hukum, Ilmu Hukum dan Pendidikan Hukum di Indonesia Sebuah Orientasi, Yogyakarta, Pustaka Pelajar.

Rahardjo, Satjipto, 2007, Mendudukkan UUD, Suatu Pembahasan dari Optik IImu Hukum Umum, Semarang, Undip Press.

Safaat, Muhammad Ali, 2015, Standarisasi Pendidikan Tinggi Hukum, Malang, Setara Press.

Sutiyoso, Bambang, 2005, Aspek-Aspek Perkembangan Kekuasaan Kehakiman di Indonesia, Yogyakarta, UII Press.

\section{Internet:}

Komisi Pemberantasan Korupsi, tersedia di website https://www.kpk.go.id/id/statistik/penindakan/109-statistik, diakses pada tanggal 26 Juli 2021.

Indonesia Corruption Watch Jakarta, tersedia di website https://www.antikorupsi.org/sites/default/files/tren korupsi 2015 dan 2010-2015 151124 0.pdf, diakses pada tanggal 26 Juli 2021. 


\section{Jurnal dan Prosiding:}

Agiyanto, Ucuk, "PENEGAKAN HUKUM DI INDONESIA: Eksplorasi Konsep Keadilan Berdimensi Ketuhanan", Hukum Ransendental, hIm 495.

Budiono, Arief, Siti Syahida Nurani, Ucuk Agiyanto, "Pendidikan Hukum yang Bervisi Keadilan Berdasarkan Ketuhanan Yang Maha Esa", Prosiding Konferensi Nasional ke-6:Sosial dan Politik, Pemikiran Islam, Hukum, Kesehatan, Yogyakarta, Program Pascasarjana Universitas Muhammadiyah Yogyakarta, 8-9 September 2017.

Bukido, Rosdalina, "Paradigm and Reality of Law Enforcement in Indonesia", Jurnal IImiah AlSyir'ah, Vol. 4, No 1, 2006.

Dwisvimiar, Inge, "Keadilan dalan Perspektif Filsafat Ilmu Hukum”, Jurnal Dinamika Hukum, Vol. 1, No. 3, September 2011.

Khambali, Muhammda, "Fungsi Filsafat Hukum dalam Pembentukan Hukum di Indonesia", Supremasi Hukum, Vol. 3, No. 1, Juni 2014.

Roihanah, Rif'ah, "Penegakan Hukum di Indonesia: Sebuah Harapan dan Kenyataan”, Justicia Islamica, Vol. 12, No 1, 2015.

Sidharta, Arief, "Pendekatan Hukum progresif dalam Mencairkan Kebekuan Produk Legislasi," dalam Moh. Mahfud MD, Sudharta, Sunaryani Hartono, et.al., 2013, Demokrasi dan Gerakan Pemikiran Hukum Progresif (Konsorsium Hukum Progresif Universitas Diponegoro Semarang), Yogyakarta, Thafa Media.

Situmaeng, Sahat Maruli Tua, "Kebijakan Kriminal Dalam Penegakan Hukum Untuk Mewujudkan Keadilan Dalam Perspektif Hak Asasi Manusia", Res Nullius Law Journal, Vol. 1 No. 1, Januari 2019.

Syaifuddin dan Ade Kosasih, "Reorientasi Arah Kebijakan Pendidikan Tinggi Hukum dalam Upaya Membentuk Penegak Hukum Profesional”, Vol. 3, No. 2, 2018. 